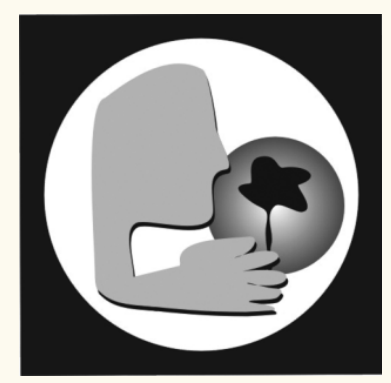

Sustentabilidade e $\mathrm{m}$ Debate

\section{Individual Land Tenure and the Challenges of Sustainable Land Use and Management in a Semi-arid Region of China}

\author{
Yongjun Zhao ${ }^{1}$ \\ ${ }^{1}$ International Alliance on Land Tenure and Administration \\ Groningen Centre for Law and Governance \\ Faculty of Law, University of Groningen, The Netherlands \\ Email: yongjun.zhao@rug.nl
}

China's farmland tenure, characterised by a household responsibility system (HRS) and collective landownership, has contributed to the continuation of poverty and natural resource deterioration in semiarid regions. Incongruent with local ecological, social and political conditions, the HRS has been linked to rising social and political tensions. Drawing on ethnographic research in Guyuan County, North China, this paper provides peasants' experiences of and views on the land issue and examines the linkages between land tenure, poverty and the governance of natural resources - grassland, forest land, farmland and water. It shows that an appropriate land tenure system can only be achieved if the fragmentation and individualization of the HRS are reformed through an innovative institutional design. The paper also contributes to a critical understanding of China's agrarian reform by articulating the need for land tenure diversity serving the overall goal of sustainable land use and management and shaping sound statepeasant relations.

Key-words:land tenure, poverty, environment, governance, institutions. 


\section{Introduction}

Land desertification is one of the major environmental challenges to be faced by the Chinese government, at least if it seeks to achieve a sustained and rapid economic growth through tackling poverty and unsustainable natural resource use and management in vast regions of the country. In Northen China, for instance, dust stor$\mathrm{ms}$ are affecting the capital city, Beijing, as well as other major cities. Frequent occurrences of dust storms in the agro-pastoral zone of that region affect the efficient use of farmlands and grasslands under semi-humid and semi-arid conditions. The management of land desertification has become a major topic in the government's environmental agenda (WANG et al., 2005). This region is also among the most affected by the sharp reduction of cultivated land, posing a major threat to the livelihoods of poor peasants (LIN $\&$ HO, 2003).

Greening the region through ecological construction is a major policy initiative of the central government, seeking to drastically improve the rural environment by enhancing the vegetation cover (JIANG, 2006). However, this effort is severely undermined by the adverse effects of an economic development advancing over natural resources, as most reform policies have accelerated rural land degradation (WILLIAMS, 1996; MULDAVIN, 1997; SANDERS, 1999). It is argued that it is the local government's aggressive efforts to improve grasslands and pastures that have caused this failure, for they disregard the ecological processes that characterise dry regions. By focusing on greening or equating an ecological construction with intensive land-use practices, this pursuit of short-term gains has met unintended consequences (JIANG, 2006).
Furthermore, the organisation of ecological construction is predicated on land tenure reform in the post-reform era, during which the former commune was replaced by the Household Responsibility System (HRS) in the early 1980s, as seen across China. The HRS allows the distribution of commune-held land and production resources to households which are entitled to use the resources for long periods by following the rules of government, while landownership remains with the village collective. Farmland is often distributed among households, and fencing or enclosure of grassland for grass rehabilitation and tree planting is used as a profound approach in order to offer the households relevant incentives. This is done under the assumption that they will have ample space to exercise their rights and gain direct benefits (JIANG, 2006). This approach was practical and successful - to a limited degree- in stimulating agricultural production. By the mid-1980s, total agricultural output grew by no less than 7.4 percent per year (HUANG, 1998). Chinese peasants had enjoyed greater freedom to sell surpluses after fulfilling obligatory grain quotas as compared with the commune era.

Since 1985, China's agricultural growth has slowed down. Rural environmental degradation and depletion of natural resources have made many people fall back into poverty (LI et al., 2005). Many scholars hold the assumption that the both the retarded growth and the continuing poverty are caused by the lack of clear-cut private titles to land as farmland ownership remains with the village collective. Such an institution is often viewed as ambiguous in the light of the mounting evidence of illegal land expropriation, land conflicts and more importantly, unsustainable land use and management. Collective ownership is often believed to obstruct the development of a healthy rural land market, which is the 


\section{Individual Land Tenure and the Challenges of Sustainable Land Use and Management in a Semi-arid Region of China}

key to the realization of economies of scale in agricultural production and poverty reduction. This two-tiered rural land system, which combines public ownership with private land use rights is also prone to corruption and rent seeking by local elites. To capitalize on the advantages of the current HRS, some scholars have argued that China would need a more individualistic institution that facilitates the development of tradable land rights or a rural land market under the rule of law (LAI, 1995; CAI, 2003; CHIN, 2005; also see HO, 2005; SZIRMAI, 2005).

Bramall (2004) argues that one should not overestimate the role of HRS in the Chinese agricultural system. Rather, government intervention, technological advancement and natural conditions have played an even more important role. The current small-size household farming system has caused major problems. These include fragmentation of land, land lost to paths and boundaries and conflicts over access to irrigation systems among village groups. Moreover, it makes large-scale agricultural production extremely difficult. Access to land has not been the basis for China's agricultural prosperity. Land is valuable because of price support for agriculture rather than for the efficiency of small-scale farms.

Transforming the HRS into a more individualistic land tenure system may not provide a viable solution. As $\mathrm{Hu}$ (1997, p. 175) points out, the current land tenure system has encouraged short-sighted decisions and the irresponsible use of land resources by peasants. Peasants pursue immediate and short-term gains, something that is exacerbated by land fragmentation. The latter hampers irrigation and drainage and leads to the degradation of China's agro-ecological environment. Local governments do not function effectively in organising agricultural production and overall rural development due to a lack of re- sources and democratic governance. On the one hand, the lack of resources and sound governance has hindered their role in sustainable rural development. On the other hand, slow agricultural development has generated insufficient resources for local governments to deliver basic rural services. Moreover, the Chinese peasantry, to a large extent, has not been organised in a way that their land can be better utilised and managed. As a result, they have not managed to gain substantial benefits from their land.

In semi-arid regions of China, the goal of the government when applying the individualist land tenure reform of the HRS - averting the tragedy of the commons (HARDIN, 1968)has not been met, as it is interwoven with complex ecological, social and political conditions. This paper sheds light on the current debates described above and challenges any preconceived model of land tenure in an attempt to explain its linkages with natural resource governance and rural development. Moreover, it shows how the HRS actually fragments rural social and political relations. Drawing on the case study of a nationally designated poverty-stricken county, this paper also explores the underlying institutional constraints, especially those concerning the major pitfalls of the HRS in governing the use of land resources by the poor. This people have seen their livelihoods become more vulnerable to the degradation of grasslands, forestland and farmland. This paper also describes the linkages of peasant livelihoods, land-induced conflicts among different actors and their contestations over resource utilisation. It suggests the need for policy changes to allow for peasants' collective choice over more appropriate land tenure systems contributing to sustainable land use and poverty alleviation in semi-arid regions of China. 


\section{Ecological Conditions, Poverty and Agricultural Policy Response}

This case study is based on the fieldwork conducted in Guyuan County, Hebei Province, in 2008. The research methods were mainly qualitative, as it was extremely difficult to gather data from household surveys and since published data is scarce. I used participant observation as the main tool to get closer to the interviewees and to learn about their livelihoods and land use practices. However, most of the interviewees were reluctant to speak given the sensitivity of the research topic. I still managed to gather the views of 30 informants from county and township governments and local peasants in 8 villages of slightly different economic and natural conditions. The field data was gathered from government reports - both published and unpublished - as well as from policy documents.

The mountainous Guyuan County of Hebei Province has a total area of 3,654 square kilometres and a population of 230,000 , distributed in 124 villages (see Map 1). Guyuan also falls within the ecologically-strategic region under the Three North Shelterbelt Programme aimed at protecting China's semi-arid and arid land from degradation. The Chinese government started this programme in 1978 with a plan to spend 40 billion Yuan ( 1 US Dollar $=6.66$ Yuan $)$ over 70 years in order to create 35 million hectares of human-made forest. Perhaps as the largest government project to re-engineer the rural landscape (JIANG, 2006, p. 1913), the programme also envisaged preventing sand storms from entering inner regions, such as Beijing. With an average annual precipitation of $392.3 \mathrm{~mm}$ (WANG et al., 2005 , p. 2403), water shortage is a major constraint to farming. Hebei, together with other provinces in North China, produces almost 25 percent of China's total agricultural output, although it has at its disposal only 5 percent of the county's water resources. Irrigation is extensively used in agriculture (KAHRL et al., 2005, p. 13). A significant part of its soil is covered with sparse vegetation as a result of salinisation and alkalisation (WANG et al., 2005), although large tracts of grassland and forests spread out in certain parts.

Guyuan is highly prone to natural disasters such as droughts, which affect an average of 30 percent of Guyuan's farmlands. Economic deve-

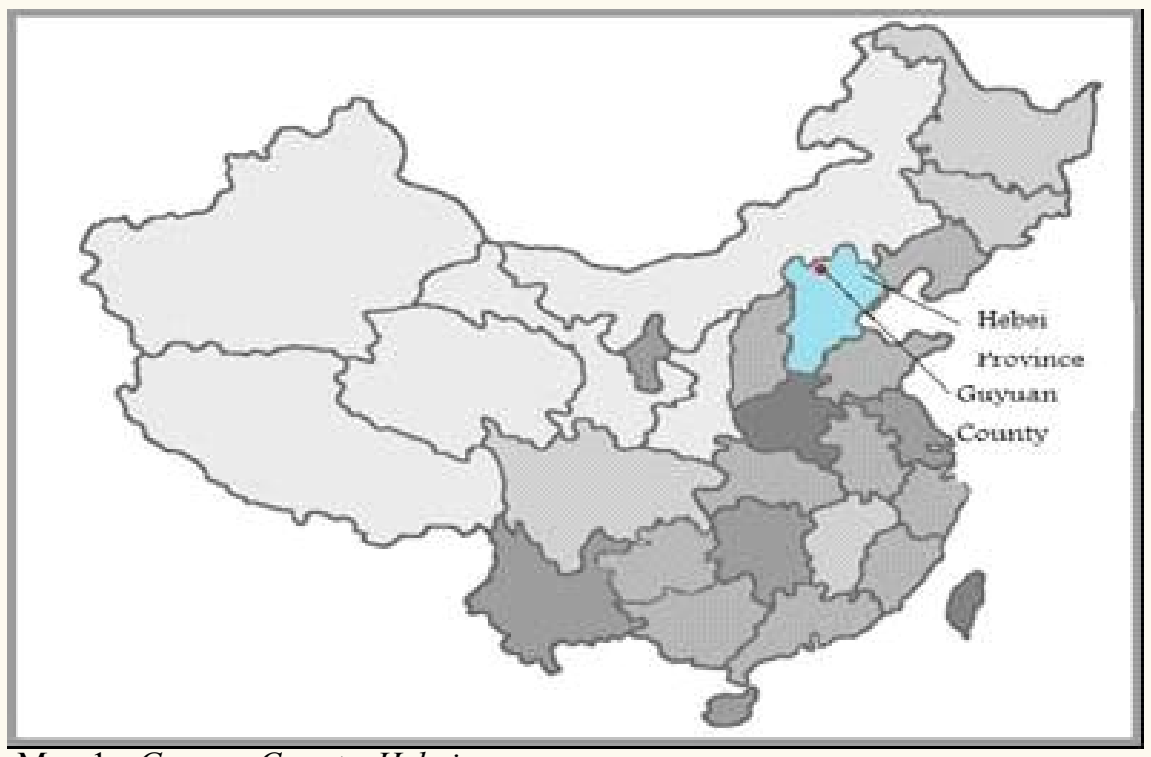

Map 1. Guyuan County, Hebei 
lopment has exacerbated this situation, as farmland, grassland and forests losses are rising. Accordingly, the natural resource base, especially soil fertility and groundwater levels, has declined dramatically. The local economy is constrained by unsustainable natural resources use and management. Poor access to public infrastructure and technical services has led many peasants to pursuit better farming and marketing options for their production (GUYUAN COUNTY GOVERNMENT, 2003, p. 97).

Guyuan features a combined economy of cultivated farming, animal husbandry and tourism, while the presence of industries remains minimal due to its various natural and infrastructural constraints. With an average of 0.43 ha of arable land per capita, it has been a nationally designated priority poor county since 1994 . A total of 124 villages, with a population of 93,069 , or over 40 percent of the total population of the county, are targeted for poverty alleviation. Despite the progresses made in the promotion of large-scale vegetable farming since 1998, there are still 78,600 people living on an average annual net income of 100 US Dollars or so. Poverty reduction continues to be a major task of the county government (GUYUAN COUNTY POVERTY ALLEVIATION OFFICE, 2007).

Since 1998, the county government has spearheaded the development of agribusiness enterprises on the assumption that this trajectory would enable different villages to develop their economies of scales. Animal husbandry and vegetable farming have been promoted as the most important enterprises for poverty reduction. It has become a well-known region for the supply of milk, beef and vegetables to other parts of the country, especially the North. In 2007, for example, 80 percent of the villages or 40 percent of the population were involved in vegetable far- ming, using 15 percent of the arable land (GUYUAN POVERTY ALLEVIATION OFFICE, 2007).

In comparison, cash crop farming in the county was minimal before 1998. Traditional crops such as oat and flax were widely planted for both domestic use and the market, with tiny profits. Paradoxically, these crops are more resistant to droughts than other vegetables. The introduction of the latter was assumed to be a quick fix to prolonged poverty, yet the extent to which poverty has been reduced is limited. While peasants shifted their traditional farming to the "modern" forms, the majority of them have not benefited from this switch. Natural disasters, water shortage and a lack of collective organisation of the farmers, constrain peasants' efforts to maximize farming efficiency and market access. Both the county's government and the peasants have voiced their concerns about the sustainability of the current farming methods in the light of these challenges. Above all, the peasants' lack of information about the market conditions and on off-farming employment opportunities has further complicated their already difficult livelihoods.

\section{Changing Land Relations: From Mutual Help to Conflict}

Understanding the history of land tenure reform is important for the analysis of changing land relations, which are central to rural development and to the governance of natural resources and village affairs. In fact, land reform in Guyuan differed little from the rest of the country. Before 1949, most agricultural land in this region was owned by landlords, rich peasants and merchants. Ordinary peasants owned little or no land at all. Only a small number of poor peasants 
managed to become smallholders after many years of hard work and savings. The land occupation ratio of the rich to the poor was nearly $8: 1-$ an indicator of a high level of social and economic inequality. The majority of the peasants maintained their livelihoods through renting the land of the landlords and rich peasants. Land transactions took different forms, which included land leases, sales, mortgages and the hiring of farm workers by the landowners.

The land revolution led by the Communist Party called for the abolition of the exploitive feudal land relations with the goal of uniting the poor peasantry in order to overthrow the Nationalist government. Many landlords' landed properties were confiscated and redistributed to the poor peasants. This victory faced an immediate challenge for agricultural development, since it was a drastic process of severing the old productive relations. Peasants who received redistributed land could hardly cope with the shortage of labour, livestock and machinery, all essential to efficient farming. Peasant cooperation became a necessary institution to deal with these problems. After 1950, many temporary and yearround mutual help groups based on voluntary principles were established. These groups with varying numbers of participant households played an important role in offsetting the shortage of human and technical capital through the exchange of labour, livestock and equipment. During this period, the number of mutual help groups increased substantially. For instance, in 1950, only 2.8 percent of the households were involved; in 1954, this number reached 81.7 percent (GUYUAN COUNTY GOVERNMENT, 2003, p. 197).

The establishment of peasant production organisations would not have been easy without government dominance and intervention. Their transformation went through three stages. At the first stage, in 1952, primary agricultural cooperatives were piloted and established along the whole county. Individual households remained as the landowners, but also as cooperative members to receive the benefits based on their labour contribution. Land use, management and agricultural production were all arranged by the cooperatives. As the second stage started in 1956, the primary cooperatives and earlier established mutual help groups were transformed into advanced agricultural cooperatives. Collective landownership replaced the old private ownership. All peasant households automatically became members of the cooperatives, which arranged farming and distributed production materials to the members. At the third stage, these cooperatives were transformed into communes - a larger institution displaying collective ownership of landed resources. Underscored by a high-level of planning and bureaucracy, the communes quickly showed to be ineffective in accomplishing farming organisation and rural development. The local government attempted to improve their efficiency, but it did not provide incentives to the members to stimulate agricultural production. Yet, this failure did not fully lie in the commune itself. The Cultural Revolution (1966-1976), as characterised by fierce political struggles, contributed to the destruction of social and economic relations at all levels, which obstructed and did not leave space for further development of the communes (GUYUAN COUNTY GOVERNMENT, 2003).

In Guyuan County, the HRS was first introduced in 1979 in some pilot villages. This introduction proved to be very difficult. As it had happened with the previous policies on the models of cooperatives and communes, its adoption was performed through strong administrative 


\section{Individual Land Tenure and the Challenges of Sustainable Land Use and Management in a Semi-arid Region of China}

measures and without full peasant consent. Land, labour, livestock and equipment were allocated to individual households, which were given the responsibility to meet production and other economic quota and taxes set by the local government. It was expected that the HRS would provide peasants with more incentives to cultivate their land, but the outcomes have not been prominent with regards to poverty levels and natural resources degradation. Moreover, from the very beginning the HRS cultivated the seeds of inequality, as large farms were leased to the socalled capable households. During the 1970s and 1980 s, these farms were run with a huge loss of profits and property due to mismanagement and to weak governance. They were thus returned to collective management. In 1993, the whole county followed the call of the central government to stabilize and improve farmlands, contracting relations by granting 30 years of land use rights to the households. And in 1997, a second round of farmland leasing was carried out with the perspective of clarifying and documenting land contracting rights and improving land tenure security. The latter was assumed to be important for the stabilization of land relations and for fostering land use rights transfers among the households, as some peasants would prefer leasing their land to others and undertake off-farm employment (GUYUAN COUNTY GOVERNMENT, 2003). In short, the egalitarian principle and practice concerning agriculture gradually receded with the introduction of the HRS, whose alignment with state policies on agricultural output to be met by households does not always suit the peasants' need for better living conditions and access to social services (CHANG, 1994).

The practice of farmland leasing quickly triggered land conflicts among contractors, village collectives and local government after 1997.
Affected peasants lack the power to hold the local government accountable and to negotiate terms of conditions with it. Village collectives are sometimes accused of mishandling of land allocations. Those households with close relationships with the village leaders sometimes receive more and better quality of land than the others and even do not fully comply with their contractual terms. In some cases, the land of those who have migrated to cities is intentionally kept and redistributed to others. In the event of the migrants returning to their homes when they were unable to find a permanent stay in the cities, they found that their land had been taken away. This is the most critical factor for disputes and conflicts between peasants and village leaders. ${ }^{1}$

Obviously, how to manage appropriate land use for the benefit of the poor presents a daunting challenge for local governance. This challenge also exhibits the weakness of the HRS in securing peasants' land use rights. This historical account shows that none of the land tenure regimes have worked effectively. Rather, they have undermined the power of the poor and led to rising social inequality and conflicts in the countryside as will be discussed in the following sections.

\section{Fallacies of Land Law and Policy}

\subsection{The Grassland Enclosure Policy}

Following the overall goal of the Chinese government in practicing the scientific development concept that emphasises human-nature harmony, Guyuan is listed in the provincial and national ecological construction plan. The optimised use of its fragile natural resources, such as grasslands, has become a primary goal of the county government. A major highlight of this goal 
is to roll out the grassland enclosure and animal husbandry prohibition policy, as the carrying capacity of the grassland is claimed to have reached the lowest level beyond government control. In this regard, the local government determines to ban the traditional method of grazing, deemed to be disorganized and attributable to the tragedy of the commons. Moreover, this policy represents a major move towards the implementation of the 2002 Grassland Law of China that sets a strong mandate for local governments to properly preserve grasslands. This law stipulates that the ownership of grasslands rests with the state, which allocates use rights to the village collective. The latter is allowed to lease the land to individual households. In particular, Article 33 of the Grassland Law states the following:

Contractors for grassland management shall make rational use of grasslands, and they may not exceed the stock-carrying capacity verified by the competent administrative department for grasslands; they shall take such measures as growing and reserving forage grass and fodder...in order to keep the balance between grass yield and the number of livestock raised (GOVERNMENT OF CHINA, 2002, p. 7).

This law reflects the government's call for the arbitrary management of grasslands in use of the carrying capacity concept. It marks no difference from the 2002 Rural Land Contracting Law in terms of granting land use rights to individual households. Accordingly, a large part of grasslands in Guyuan has been partly contracted out to individual households who are required to sign their use rights contracts with the county Agricultural and Animal Husbandry Bureau. In principle, their grazing rights are set against the numbers of livestock to be kept by them, which is hard to implement. In practice, the delimitation of household-based grassland will automatically lead to the reduction of the number of livestock. This measure is assumed to be useful for the preservation of the land, for which peasant users should bear responsibility. In a few cases, some grassland areas are kept on the hands of the village collective purely for the purpose of nature conservation. Such areas -usually depleted or prone to increasing levels of degradation- are fenced off for rehabilitation. Apart from the contracted and preserved grasslands, there is only a small proportion of the land left open to communal grazing.

To the local government, the administration of grassland protection is too costly and difficult to manage, since the peasants can find ways to cut the fence and enter the prohibited areas. The grassland contract management has not succeeded in fully registering the peasants, some of whom have not applied for the contract certificate as required by law. For those who have the certificates, they are only allowed to graze appropriate numbers of livestock; but in practice, one can hardly tell whether these numbers have been followed. Furthermore, there is a lack of institutional mechanisms for effective monitoring as county and township governments and the village collective do not have clear roles to play and thus do not think that they are solely responsible for it. They often blame each other for this rather than putting forward more coherent policies for sustainable land management.

The ineffectiveness of the law in the view of the local government is due to peasants' lack of "modern knowledge" of livestock rearing and grazing. To influence peasants' grazing behaviour on the basis of ecological science (see JIANG, 


\section{Individual Land Tenure and the Challenges of Sustainable Land Use and Management in a Semi-arid Region of China}

2006), further attempt was made to introduce new methods to prevent the peasants from grazing outside their homes. However, as these methods require improvements in the use of fodder and feed, it was too costly for the peasants to follow. The peasants have continued to ignore these calls and managed to avoid the inspection of the local bureau staff regarding the use of the grassland. Some rehabilitated sites, despite being well protected for some time, have now become degraded again due to a peasant "invasion". Some large parcels of grassland contracted out were found to be used for cropping and other functions, which were not allowed by law. Nonetheless, with the implementation of the 2003 Decree of Grazing Prohibition, access to grazing has become more and more difficult for the peasants, who complained that their income from farmland cultivation was so limited that they had to rely on grazing to supplement it. The lack of adequate access to grassland further contributes to their vulnerable livelihoods (XINHUA NET, 2006).

The widespread grassland degradation indicates that relevant grassland laws and policies place overt emphasis on management issues rather than linking it with viable options for peasant livelihoods. To the peasants, the traditional method of grazing has certain cost-effective advantages, including flexible management of the livestock. As their own grazing rules are not considered by the government, they do not believe that the "exotic" method of grassland enclosure is in their best interests. In fact, as in other regions, grassland enclosure has contributed to overgrazing and thus land degradation (JIANG, 2006). Furthermore, when there is not much leeway for them to use even their own contracted grassland as it is small in size, grazing on the preserved grassland becomes unavoidable. For instance, 95 percent of the informants acknowledged that they knew what was happening, but did not know how to deal with it. The rest simply did not believe that they themselves should be blamed. Above all, they saw livestock husbandry as a better way to fight poverty than other practices such as vegetable farming. And when they saw the immediate benefits from it, they simply wanted to forgo other scarce options.

The lack of effectiveness of policy instruments indicates that as in many other parts of the country grassland preservation programmes are not coupled with appropriate poverty alleviation strategies. Moreover, no community-based land management models based on household tenure are found (see BANKS et al, 2003). In Guyuan, grazing remains as the most profitable means of livelihoods for the majority poor, as they cannot rely upon farmland production due to environmental and economic constraints as seen in later discussions. They showed discontent over the county government's grassland reclamation policy which caused an increase in poverty and rising social conflicts in the village (Xinhua Net, 2006). Their views on participation in grassland use and management have not been at the top of the development agenda of the local government.

Furthermore, grassland management is often arguably compounded by the fuzziness of the heterogeneous and hybrid property relations, where village collectives and even local governments have more power to determine land uses than the peasants, and where lines of responsibility of grassland management are not clearly demarcated among different state and non-state actors (see HINTON, 1990; YEH, 2004). These factors contribute to poor grassland governance, which has had a direct impact on the perceptions of the peasants regarding grassland use. A prominent example is the Ministry of 


\section{Sustentabilidade em Debate}

Agriculture's national circular in 2006 on its decision to penalize the misconduct of Guyuan local government staff and land contractors in grassland use. ${ }^{2}$ It was reported that the county government and a village committee had contracted the land owned by the government and village collective respectively to local businessman and certain peasant households without transparent procedures made known to the local community. The latter had no idea of how local government line agencies played a key role or were involved. This led to the conversion of large pieces of the grassland into other land usages. According to the 2002 Grassland Law of China, land contractors must maintain the original status of the land. In the two reported cases they managed to cover up their purposes by stating that they wanted the land for eco-tourism development and would take care of the land to abide by the law. Only at a very late stage did the local community notice that they had changed large plots of land into cropland and fenced these parts off from the rest of the community. In fact, the two contractors even occupied the land before the local bureaus formally approved their applications (Ministry of Agriculture, 2006). This means that to a certain extent, the current tenure system has favored the powerful groups in their uses of the land for their own benefits, which is commonly found in other parts of China.

\subsection{Collective forestry reform}

Tree plantation and preservation are regarded as equally crucial as grassland preservation to ecological restoration. The county government has made the forest a fundamental natural resource to be preserved and to be free from illegal logging by establishing forest protection teams in each township. To a large extent, their measures have been effective in this respect. But the peasants are not offered strong incentives in any of the forest plantation programmes. For instance, the most prominent land conversion or "green for grain" programme aimed at dramatically increasing forest coverage to combat soil erosion and flooding ${ }^{3}$, as in the other parts of the country, has proved to be unsuccessful due to many factors, one of which is a lack of linkages between tree planting and its derived benefits. For instance, in recent years peasants received only an estimate of 160 Yuan annually per mu ( 1 ha $=15$ $\mathrm{mu}$ ) of their land converted to forest land. And this included both compensation and a subsidy from the local government. This tiny amount was just impossible for the peasants to maintain their livelihoods when their land was devoted to forests. Given the climatic conditions in this dry region, it takes approximately 15 years for the trees to grow. Also, the planted trees had not been well cared for, and some even died off a few years later. Furthermore, as reflected by the county Forestry Bureau, peasants' lack of ownership over the trees put the sustainability of the forest programme at risk. This also applies to those trees under the direct management of the village collective. In the end, this programme was suspended. Obviously, balancing the interests of the local government and peasants in this sector poses a difficult challenge to decision-makers (see STRAUSS, 2009).

To address disincentives and to encourage the peasants to take an interest in the forest land, the Forestry Bureau follows the example of the collective forestry tenure reform in southern China, where cases of success are documented. ${ }^{4}$ In fact, this initiative adopted elsewhere was taken up by the State Council, which promulgated the 2008 Opinions on Comprehensive Collective Forest Land Tenure Reform. Essentially, this policy is to emulate the HRS in the management of 


\section{Individual Land Tenure and the Challenges of Sustainable Land Use and Management in a Semi-arid Region of China}

collective forestry land and peasants' ownership of forests across the country. It is seen as a major measure to boost the enthusiasm of the peasants, increase their incomes and make forestry sustainable. It stipulates that production and management of forestry should be entrusted to peasants by issuing extendable 70-year forest land use contracts, while the nature of collective ownership should be maintained. It calls for ensuring equal access to peasants' forestry land rights and guaranteeing their rights to know and participate in the decision-making process affecting their land rights. Moreover, peasants are allowed to transfer, lease or mortgage the forest land use rights within the tenure period. Local government is asked to extend financial institutional services to the needy and establish forestry insurance to protect the peasants from natural disasters. This reform also makes an explicit call for strengthening public services to support forestry cooperatives and enterprises, which should play a leading role in forest management and production to promote economies of scale. It is set to be completed over a 5-year period, during which forest land rights certificates should be issued to the individual households based on the registration of their contracted forest land (Government of China, 2008; Xinhua News Agency, 2008).

In fact, long before the promulgation of this policy, the Forestry Bureau had tried to emulate similar measures to undertake collective forestry reform - with very limited success. The slogan of strengthening individual households' awareness and forest management ownership was used to rationalize the policy and to motivate the peasants. However, the latter did not perceive this policy as something new, as the forest had already been under the management of the collective. Moreover, granting long-term use rights might incur more institutional burdens to shoulder for the househol- ds, since they do not expect to gain benefits from the forest products which are not as marketable as in the past. As a staff member of the bureau indicated,

The collective forestry reform here cannot be compared with that of the South, where the peasants can simultaneously plant other economic crops with the forest. Here, the climatic conditions just cannot allow this. That is why it is not attractive to the peasants. So, we may not be able to continue the reform later on (Interview, July 2008).

While the use rights for a large proportion of the collective forests were said to be granted to individual households, the latter were reluctant to receive the use rights certificates. How to divide and redistribute the collective forests to individual households is never an easy task for the Forestry Bureau. To a large extent, the forest land is supposed to be redistributed to the peasants on the basis of equitable conditions in terms of the quality of the land and the number of household members. In cases where the land with poor quality cannot be redistributed easily, it should be done through lease, tender and auction to the needy. When this cannot be realized, it rests with the village collective. All these steps require sound planning and participation of the community in deciding on how the forest land can best be used and managed. Moreover, the peasants need to know whether the forests contracted to them are of economic value to them. Otherwise, they will lose interest in it (BAI, 2007). The lessons from this county and other regions indicate that in most cases, local governments pay insufficient attention to the needs of the households and collective efforts (MIAO \& WEST, 2004). As a result, the reform can easily incur discontent and even con- 
flicts among various stakeholders involved, which deserves further studies.

The lack of capacity of the Forestry Bureau to control inappropriate forest land use overshadows its overall forestry reform agenda. Some staff blamed grazing as the number one threat to forestry and emphasized the need to put a complete stop to it by severely penalizing those responsible especially the households with a big number of livestock. Obviously, a lack of coordination between different line agencies constrains any conceived efforts in sustainable forest land management. These factors are compounded in the ongoing process of forest decentralization, where local government lacks resources and capacity to implement the reform agenda (see LIEBERTHAL \& LAMPTON, 1992). What mechanisms should be established to empower the peasants to keep the local cadres in check remain unclear. As a result, "the leadership of the rural collective, including the Party secretary, the village head and other village committee members, may co-operate and pursue personals interests as a collective" (CAI, 2003, p. 668).

In short, policies of grassland and forest protection and utilization have been mutually exclusive. The local peasants could only resort to short-term gains, sometimes at the cost of these resources (CAI \& WANG, 2006). A lack of coordination in land use planning and management contributes to the failure of the programmes in which the peasants are caught in a vortex of uncertainty regarding the changes in land use imposed by the government. The relationships between natural resource tenure reform, poverty and the environment have not been sufficiently addressed in an integrated manner by the local government. The reform of land resource tenure from collective to household-based institutions signifies a simplistic approach that departs from the biophysical, economic and political constraints.

\section{Farmland Use, Conflicting Interests and Peasant Contestations}

\subsection{Farmland for Livelihoods}

Rural development for local peasants is nothing more than the maximization of the utilization of the available resources in the pursuit of quick results in the reduction of poverty. Their attachment to land, pasture, forests and other resources embodies their pragmatic values towards their livelihoods. Yet, peasant relations have become less dynamic than the commune period in the 1960s and those found in traditional ethnic minority groups. With the market-oriented policies infiltrating their communities, individual interests override the mechanisms of collective choice and decision-making on the use of the resources for the benefit of all. This can be seen in the cases of farmland use more clearly.

Vegetable farming constitutes a primary source of income for most households in areas where soil conditions are favorable, although the increasing level of water scarcity has becoming a problem. It requires reasonable capital inputs in terms of time spent in the field, use of water, chemical fertilizers and seeds. Where there is a lack of technical and funding services provided by the local government, the growers are vulnerable to and incapable of effectively dealing with various natural and economic risks. The varieties of vegetables grown are limited across the county, and this unavoidably leads to competition over sales and marketing outlets. Only those households with relatively larger sizes of land manage to gain reasonable profits. Since they have no other ways 


\section{Individual Land Tenure and the Challenges of Sustainable Land Use and Management in a Semi-arid Region of China}

to sell their produce than relying on the middlemen from other provinces to collect it, quite often they are in a weak position to bargain over the prices offered.

With the introduction of the HRS, random growing of vegetables for the peasants to gain high economic returns has replaced traditional cropping to a large extent; as a result, grain production has reduced substantially. In China, between 1995 and 2001, the production of vegetables nearly doubled (LITCHTENBERG \& DING, 2008). In Guyuan, farmland fragmentation has reduced the efficiency of farming as evident in vegetable farming, which is akin to "digging the soil and land without caring about the kind of resources they will leave for the future" (HU, 1997; ZEN, 1991, p. 79).

Village life is unlike the past, when unity and mutual help played an essential role in organising the peasants. "Everyone is helping himself. We do not know about the future - we just try to make ends meet anyway. Nobody will help us", some peasants claimed. Similar remarks were also shared by the local government staff. Despite the HRS' partial success in poverty reduction, it displays an increasing weakness in uniting the poor as land becomes fragmented. The peasants have less space for the social organisation of agricultural production. And when the village collective mostly represents the interests of the local state, the role of the peasants in voicing their concerns over land use and agricultural development becomes minimal. As a result, land is nothing but a means of livelihoods for the peasants. All the informants agreed that they were not sure what farming relations in their villages exist as they worked on the land on their own. When their land use contracts expire in 30 years, they wondered whether their land rights would be altered by the local government. Facing uncertainty over land use and other associated rights and a lack of public support, many informants viewed the Chinese peasantry as the most vulnerable group in the country. These institutional constraints pose severe challenges for the sustainability of farmland use in the county.

\subsection{Conflicting Interests in Farmland Use}

Fragmented farmland use caused largely by the introduction of the HRS underpins complex peasant-local state relations as both have different or even conflicting interests in the land. As the value of the land increases with the local government gaining increasing control over it, local peasants see their land as their last resort to maintain their livelihoods.

The national policy on farmland protection places strict conditions on farmland use and prohibits its conversion into non-agricultural uses. Accordingly, the local government set the mandates for the village collective to demolish all the buildings such as pigpens in the field. And peasants' ignorance of this call would lead to forced demolition of their properties. However, when the peasants built their houses years ago, they were not informed of whether it would contravene any government policies. In fact, their ideas were even approved by the village collective. As these households are small in scale and only occupy the tiny plots unsuitable for cropping, thus literally, this act has nothing to do with farmland conversion. Seeking the support of the village committees was futile. As many of them are women, children and the elderly left behind in the village, they could not form a unified force against possible land evictions. They also knew that the peasants' weakness had led to the eviction of many of them as new land development takes place on a regular basis. 
This example also reflects that land use planning and management has never been an easy task for the local government which has been under mounting pressure to both preserve and utilize the land to promote economic development. The county does not have any foreign companies operating in it now. To attract business development, when conditions allow, the local government must provide the necessary basic infrastructure, and this requires a huge amount of funds to be allocated. However, this is extremely difficult for this nationally-designated poor county. Thus, the acquisition and consolidation of land has become a necessity in favour of corporations and real estate developers. While creating space for this development, the local government has to restrict the use of farmland for "non-agricultural" purposes by the peasants in order to strike the overall balance between farmland preservation and conversion.

The county government line agencies are trapped on the path towards economies of scale in agricultural production, making the maximization of land use and land acquisition unavoidably difficult for them. They all seemed to agree that the county had no other options but to introduce the "dragon head" agribusiness (longtou qiye) to take the lead in organizing scaled production. They complained about the peasants' backwardness of ideas, knowledge and skills in adjusting to the demands of the market economy. However, for the peasants, the lack of secure land rights and the mechanisms for transparent and effective partnership with agribusinesses could only make them cast doubt on every land use arrangements. As the local government has the mandate to push further ahead economic development, its conflicting interests with the peasants are on the rise.
The dilemma for sustainable rural development may indicate the need to reorganize the peasants who can collectively decide on how their land and other resources can be used properly. This is also a prerequisite for the healthy growth of agribusinesses. Like those pilot schemes taking place in southern China, the county line agencies staff pointed out that they should allow the peasants to become land shareholders and benefit from agribusinesses. ${ }^{5}$ Thus, the village collective should play a bigger role in uniting the peasants and assuring them better economic returns on agricultural production. Ultimately, this requires the establishment of specialized business-oriented peasant associations. However, the current policy on these organizations requires a substantial amount of capital to be registered, and this would simply mean that for the poor peasants it is impossible. Moreover, the rural societal structure is fragmented and it is extremely difficult to bring the peasants together. This also demonstrates the failure of the village collective and government policy in revitalizing the social and political dynamics of the Chinese countryside since the market reform of the late 1970s. Nearly 50 percent of the local government staff held the view that the trend of the rural economic reform should reverse the HRS into genuine collective land use and management. And this was thought to be a way to revitalize the Chinese countryside and help the peasants cope with their vulnerabilities to various social, political, economic and natural risks associated with land use. However, how to convince the peasants and give them an incentive to form relevant agribusiness groups or associations remains a challenge, for these associations may become the cause of conflicting interests rather than representing collective efforts. 


\subsection{Peasants' Contestations of Farmland Use}

The scale of peasants' self-organisation of economic, social and political activities is rather limited due to the institutional constraints as already mentioned. But they are not passive recipients of government laws and policies. Changes in the central government policy that favours agriculture, on the one hand, have created more incentives for the peasants to care about their land; on the other hand, they also spur local conflicts. Land-induced conflicts between the peasants and local cadres have become a thorny matter. A recurring example is the tension between returning peasant migrants and local carders over land reallocation. Village collectives and township governments are often complained of purposely reallocating the land when the original legal users migrate to the cities. In this case, Guyuan resembles the rest of the country, where large numbers of impoverished rural people have become migrants as part of the "floating population" of $200 \mathrm{mi}$ llion to seek temporary work in cities (ZHANG, 2001; SOLINGER, 2002). To the township government, the land left by these migrants should be redistributed to accommodate the needs of other groups. Paradoxically, this practice is no longer permitted by law that aims to ensure land tenure security and explicitly calls for an end to land readjustments. ${ }^{6}$ As one member of the local township government staff remarked, The current land law and policy do not really take into account the local conditions seriously. And it is sometimes contradictory in terms. For instance, it enshrines women's land rights. But if land readjustments are not allowed, how can we give land to the women who marry men in our villages? Besides this, the recent agricultural policies have actually extended the invitation to the migrants who want to return to farming. When they migrated to cities, they left their land idle and let us manage it. We then leased it to others who could farm the land. How can we return this land to them when it is in others' hands? Their discontent with us has led to skyrocketing cases of petitions, but we find it hard to meet their demands (interview, July 2008).

These conflicts do not indicate that local peasants have more systemic concerns over how their land can be utilized in a sustainable way. Yet these conflicts show the peasants' growing concerns about their rights, livelihoods and ineffective policies in the context of widening social inequality between different groups. As a result, land readjustments may privilege some while marginalising others due to the practice of personalism, clientelism and networking tactics carried out by the dominant group (see NONINI, 2008). Moreover, peasants' struggles for land use are sporadic and seldom organised systematically in terms of the creation of effective groups that can maximize their influence and collective force. This may indicate that the current HRS is inextricably linked to this, with its nature of fragmentation of agricultural production as well as social cohesion. Paradoxically, 90 percent of the interviewees indicated that they would rather keep the HRS, as they did not trust the collective. The rest either preferred the old commune system or simply had no preferences. But they all thought that development policies and laws concerning their land rights should be strengthened. Some even expressed their inclination towards land privatisation, which would ideally enshrine more secure rights for the peasants. But all of them expres- 


\section{Sustentabilidade em Debate}

sed their concerns about the absence of viable property relations for sustainable land use and management and poverty alleviation as a whole.

\section{Conclusions}

This study indicates that the conventional individualistic approach to land resource tenure has not brought viable solutions to the complexity of rural poverty and its underlying institutional constraints. Relying on market-oriented development models, China's economic success has incurred in severe social and environmental costs. To a certain extent, the replacement of the collective institution of the commune with the HRS has exacerbated its developmental dilemma. The serious flaws of this approach and the rhetoric of development policies are not responsive to local biophysical, political and economic realities (GUPTA, 1998). The HRS is attributable to short-term development gains rather than sustainable resource use in the long run. Moreover, it is interwoven with the absence of appropriate institutional mechanisms for effective sustainable land use and management in a region where poverty and natural resource degradation prevail.

The HRS has been a contributing factor for the fragmentation of social relations and the lack of capacity of the local state and lack of collective action of local community in development processes. The local state puts overt emphasis on meeting higher-level state demands rather than serving the community needs first (CHRISTIANSEN \& ZHANG, 1998; KUNG, et al, 2009). This is reinforced by the HRS whereby communities are marginalized in land use planning and broader-level of village governance. In the context of rising social inequality across the country, it becomes more difficult for the state to organize the peasantry. The fact that some peasants support the HRS actually implies that they mistrust other possible measures imposed upon them by the state. In other words, they are not given the space to explore other systems of land tenure by the state.

It is important to understand how mechanisms of power have been able to function within the society and between society and state in order to investigate the agents responsible for social constructs (FOUCAULT, 1986). In this sense, this case study shows that although mechanisms for peasants' collective action remain unclear and even weak, their daily struggles are omnipresent in their disorganized and silent contestations. However, their resistance is not "genuine" in the sense of being organized with clear motives and goals as defined by Scott (1985). This individually-based and seemingly passive resistance to the land use institutions reveals the absence of the mechanisms for genuine peasant participation in policy-making processes concerning their land use and governance.

As the peasant-local state relations become more murky and complex, and social dynamics among different social groups become more intractable, how to revitalise the Chinese countryside by making the complex social, political and economic relationships work for the goal of sustainable land use and rural development remains an ultimate challenge for policy-makers. They need to rethink their current institutions governing farmland use and natural resource management. It is essential to tackle the structural barriers to law and policy-making mechanisms that put constraints on the representation of the peasants whose need to participate in the process should be nurtured and empowered (CAI, 2003; LI, et al, 2004).

No single type of landownership is a blueprint for sustainable land use and management 
(DIETZ, et al., 2003). A new form of land tenure congruent with local economic, ecological, political and social conditions should be explored and tested by policy-makers. This form of land tenure has to serve the needs of sustainable land use and management, which is largely impinged on state-peasant relations. In retrospect, these complex relations are shaped by land tenure arrangements. Thus, future land policy developments should be based on sound analyses of the interconnections between land tenure, land use and management and socio-political relations, the implications of which are critical for China's transition to ensure the accomplishment of sustainable development goals in semi-arid regions in particular.

\section{References}

BAI, S. Dingzhu mubiao, gongjian kenan, quebao wancheng quansheng jiti linquan zhidu gaige renwu: zai quansheng jiti linquan zhidu gaige diaodu huiyi shang de jianghua (Sticking to the target and overcoming difficulties to ensure the completion of the tasks of provincial collective forestry reform: Speech at the provincial collective forestry reform coordination meeting), unpublished speech note, 2007.

BANKS, T. et al. Community-based grassland management in western China: rationale, pilot experience, and policy implications. Mountain

Research and Development, v. 23, n. 2, p. 132140, 2003.

BRAMALL, C. Chinese land reform in long-term perspective and in the wider East Asian context.

Journal of Agrarian Change, v. 4, n. 1 and 2, p. 107-141, 2004.

CAI, Y. Collective ownership or cadres' ownership? The non-agricultural use of farmland in China. The China Quarterly, issue 175, p.
662-680, 2003.

CHANG, K.S. The social-political processes of agricultural decollectivisation in a North China commune. China Report, 30 (4), p. 395-406, 1994.

CHIN, T. Securing a rural land market: politicaleconomic determinants of institutional change in China's agricultural sector. Asian Perspective, v. 29, n. 4, p. 209-244, 2005.

CHRISTIANSEN, F.; Zhang, J. (eds) Village INC.: Chinese rural society in the 1990s. Honolulu: University of Hawai'i Press, 1998. CUI, H.; Wang, L. Tuigenghuanlin gongcheng yu nongcun shehui yunxing: jiyu hebaisheng guyuanxian de shizheng fenxi (Green for grain programme and rural society: empirical studies on Guyuan county. Proceedings of China Social Science Annual Conference, 2006.

DIETZ, T. et al. The struggle to govern the commons. Science, 302, p. 1907-1912, 2003.

FOUCAULT, M. Disciplinary power and subjection. Steven Lukes (ed) Power. New York: New York University Press, 1986.

Government of China Grassland Law of the People's Republic of China. Beijing: Ministry of Agriculture, 2002

Government of China Rural Land Contracting Law of the People's Republic of China. Beijing: Ministry of Agriculture, 2002.

Government of China Zhonggong zhongyang guowuyuan guanyu tuijin jiti linquan gaige de yijian (Communist Party Central Committee State Council opinion on promoting collective forestry tenure reform). http://english.gov.cn/jrzg/200807/14/content 1044403.htm, 2008, accessed on 20 December 2009.

GUPTA, A. Postcolonial Developments: agriculture in the making of the modern India. Durham, NC: Duke University Press, 1998. Guyuan County Government Guyuan Xianzhi 
(Guyuan County history). Baoding: Zhongguo sanxia Press, 2003.

Guyuan Poverty Alleviation Office Guyu Fupin Kaifa Gongzuo Qingkuang de Diaoyan Baogao (Research report on poverty and development in Guyuan County), unpublished report, 2007.

HARDIN, G. Tragedy of the commons. Science 162, p. 1243, 1968.

HINTON, W. The Privatization of China: the Great Reversal. London: Earthscan Publications, 1990.

HO, P. Developmental Dilemmas: land reform and institutional change in China. London \& New York: Routledge, 2005.

HU, W. Household land tenure reform in China: its impact on farming land use and agroenvironment. Land Use Policy, v. 14, n. 3, p. 175-186, 1997.

HUANG, Y. Agricultural Reform in China. Cambridge: Cambridge University Press, 1998. JIANG, H. Decentralization, ecological construction, and the environment in post-reform China: case study from Uxin Banner, Inner Mongolia. World Development, v. 34, n. 11, p. 1907-1921, 2006.

KAHRL, F. et al New horizons for rural reform in China: resources, property rights and consumerism. Stanford Centre for International Development, http://are.berkeley.edu/ dwrh/ Slides/SCID KRHZ 100105.pdf, 2005, accessed on 15 January 2010.

KUNG, J. et al Rural cadres and governance in China: incentive, institution and accountability. The China Journal, n. 62, p. 61-77, 2009.

LAI, L. W. C. Land use rights reform and the real estate market in China: a synoptic account of theoretical issues and the property rights system. Property Management, v. 13, n. 4, p. 21-28, 1995.

LI, X. et al. (eds) Environment and Poverty: the Chinese practice and international experiences. Beijing: Social Sciences Academic Press (China), 2005.

LI, X. et al. (eds.) 2003-2004 Status of Rural China. Beijing: Social Sciences Academic Press (China), 2004.

LICHTENBERG, E.; Ding, C. Assessing farmland protection policy in China. Land Use Policy, 25, p. 59-68, 2008.

LIEBERTHAL, G.; Lampton, M. Bureaucracy, Politics, and Decision-Making in Post-Mao

China. Berkeley \& Los Angeles: University of California Press, 1992.

LIN, G.; \& Ho, S. P. S. China's land resources and land-use change: insights from the 1996 land survey. Land Use Policy, 20, p. 87-103, 2003. MIAO, G.; West, R. A. China collective forestlands: contributions and constraints. International Forestry Review, v. 6 (3-4), p. 282-298, 2004.

Ministry of Agriculture Nongyebu bangongting guanyu hebeisheng guyuanxian kaiken caoyuan anjian chachu qingkuang de tongbao (Circular of the Ministry of Agriculture's decision on the inspection and punishment concerning the Guyuan County of Hebei Province's mismanagement of grassland cases), issue n. 29, 2006.

MULDAVIN, J. Environmental degradation in Heilongjiang: policy reform and agrarian dynamics in China's new hybrid economy. Annals of Association of American Geographers, 87 (4), p. 579-613, 1997.

NONINI, M. Is China becoming neoliberal? Critique of Anthropology, v. 28 (2), p. 145-176, 2008.

SANDERS, R. The political economy of Chinese environmental protection: lessons of the Mao and Deng years. Third World Quarterly, 20 (6), p. 1201-1214, 1999. 
SCOTT, J. C. Weapons of the Weak: everyday forms of peasant resistance. New Haven: Yale University Press, 1985.

SOLINGER, D. J. The floating population in the cities: markets, migration, and the prospects for citizenship. Susan D. Blum \& Lionel M. Jensen (eds) China Off Centre: mapping the middle margins of the middle kingdom, p. 273-290, Manoa: University of Hawai'i Press, 2002.

STRAUSS, J. C. Forestry reform and the transformation of state capacity in Fin-de-Siecle China. The Journal of Asian Studies, v. 68, n. 4, p. 1163-1188, 2009.

SZIRMAI, A. The Dynamics of SocialEconomic Development: an introduction. Cambridge: Cambridge University Press, 2005. WANG, S. et al. Recent land use changes in north dust storm source area affecting Beijing and Tianjin: agro-pastoral transitional zone. IEEE, p. 2402-2405, 2005.

WILLIAMS, M. The barbed walls of China: a contemporary grassland drama. The Journal of Asian Studies, 55, 3, p. 665-691, 1996.

XINHUA NET (2006) Guyuan: feifa kaiken caoyuan shijian de beihou (Guyuan: what is behind the case of illegal grassland reclamation). http://www.he.xinhuanet.com/dishi/2006-03/30/ content $6607521 . \mathrm{htm}$, accessed on 13 July 2008 , 2006.

Xinhua News Agency China to push forward collective forestry land reform. http:// www.china.org.cn, 15 July 2008, accessed on 18 July 2008.

YEH, T. Property relations in Tibet since decollectivisation and the question of fuzziness.

Conservation and Society, 2, 1, p. 107-131, 2004.

ZEN, D. Collectives' land in countryside should be used under taxation. Study on China's Land

Problems. Beijing: China Economic Press, p. 78-
81, 1991.

ZHANG, L. Strangers in the City: reconfigurations of space, power, and social networks within China's floating population. Stanford: Stanford University Press, 2001.

Yongjun Zhao, $\mathrm{PhD}$ in international development studies, is assistant professor with the Groningen Centre for Law and Governance, University of Groningen in the Netherlands. He practiced in international development organizations, NGOs and businesses in several countries. His research experiences include the governance of natural resources (land, forest and water) and rural-urban development in China and Africa and China-Africa development cooperation. His email address is yongjun.zhao@rug.nl. 
